\title{
Crisis Communication- The rise of New Brand Language in India
}

\author{
Dr Pooja Jain \\ Srishti Manipal Institute of Art Design \& Technology, India
}

\begin{abstract}
Traditionally the research on crisis communication was targeted to public and private organizations' but there is a limited awareness on crisis communication from the perspective of Indian brands.It is considered as a powerful strategic approach to reach the existing and prospective target audience during troublesome situations. Whenever a crisis occurs, there is a need of proactive, swift and comprehensive communication. In India, now days every brand has started thinking about an emergency communication plan that they may use whenever needed. Since it's all about a brand's repute when a crisis occurs, it becomes crucial to communicate with the masses addressing their immediate concerns and counter false information, ensuring that the communication language remains consistent throughout. Advertising is the key focus here since it plays a fundamental role at the junction of mass interaction. In present scenario, Social media platforms has turned out to be expedient tool for crisis communicating. But along with it, identifying the facts about the crisis and its significance is equally essential. This paper thus aims to bring forth tools and tactics of communication being used by brands before and after crisis. To better understand how this issue may affect the decisionmaking outcomes, Qualitative research approach will be taken to investigate judgement by observing \& interviewing domain experts. Primary \& Secondary data will help to evaluate the crisis response strategies taken by some power brands of India. Case study approach will yield the desired level of detail \& understanding. Conclusions point out the glaring fact that all the brands that are involved in crisis communication have been successful in retaining their social identity and acceptance with high ethical standards in regard to social responsibility. Recommendations for how crisis communication can be further improvised in practice are discussed as well as suggestions for future research are provided.
\end{abstract}

Keywords:

Brand, Crisis, Communication, Strategy

Article Received: 18 October 2020, Revised: 3 November 2020, Accepted: 24 December 2020

\section{Introduction}

Crisis communication has evolved as a new strategic approach by Indian brands \& businesses to interact with mass audience during a troublesome event. Whenever a situation of crisis occurs, proactive, quick and in-depth communication is required. It has been evidently proved in certain cases where crisis communication strategies have played a major role in disaster recovery \& business continuity. A brand often holds many promises and when they fail to meet these promises the overall image gets affected (Herbig\&Milewicz, 1995).A good brand heightens both loyalty and equity, and if it gets disturbed it may ruin the whole company. (Aaker, 2010)

Crisis, both big or small, may occur anytime in this brand business world which is prone to uncertainties and complexities with constant media acquaintance. Whether a brand is prepared enough to deal with such situations or not is the question of prime importance. This paper underpins the repercussions of a brand in crunch circumstances, especially on consumer purchase decision. In the last two decades, the Indian market has seen a drastic change in the nature of the relationship between brands and consumers. Now days' brands businesses are more responsible towards the unintended crisis situations than ever before. They feel that this is also equally import besides policy making, decision making and mapping a brand's mission with its vision. It is often observed that the consequences of the steps taken by certain brands against crisis situations not only have a wider impact on their financials but also on their social significance and consumer outreach. The whole process is further extended by taking prompt actions to face the dynamic challenges of Indian society. 
Brands currently experience a firm challenge in maintaining their positioning in the market. The most trusted formula of brand businesses is losing its relevance and also losing their grip over consumers. Today brands more often run into crisis situations due to varied reasons. It may be internal or external issues that leads to the crisis which eventually becomes difficult to surpass and in turn gains a negative publicity to that brand. Years of dedication and struggle put in constructing and molding a brand's name can be tarnished in seconds by an inappropriate tweet, some random product failures, grievances etc. Whatever be the reason, the brand managers and even the marketers have to handle this with utmost care without getting the brand image much hampered and to sustain their relations with prospective consumers. When a brand crisis happens, all the users along with the stakeholders and media channels tends to raise lot of allegations and questions about why and how it happened. Brand reputation can be effected big time through such events which also raises speculations on brands sustainability for a longer run. In the long run, it may also benefit the competitors to take away brand's goodwill and consumers at one go.

A usual crisis situation involves five phases and each of these phases asks the brand to have an open dialogue with its consumers and stakeholders. The pre-crisis phase talks about planning and informing. Brands should invigilate incipient risks, anticipate possible disaster, educate masses and propose a relevant action. The brands create communication system and messages that has potential to reach to the users and others with prior testing. During the initial phase, the communication begins when the crisis situation has already started. Considering it as a critical and a confused phase, brands provides resources for imparting apt information towards a clear and accurate direction. Even if the brand doesn't have resources in hand, their crisis communication may take a lead to reassure people that the brand is seeking a solution. The third phase is about maintenance, where a brand communicates by gathering sufficient information, evaluating feedbacks from their regular users or anyone effected by the crisis, re-interpret any sort of misinformation that has spread and continues to take care of the situation and its responses. When the crisis is in its resolution phase, it means that the situation has been ended, however the revival continues along with the communication strategies. During evaluation phase, it is very important to establish a two- way communication, so that the brand can assess the response and can look ahead to it further improvement. Here, the brand relooks upon its strategy and revise it, if needed. As wisely said by Abraham Lincoln, "Give me six hours to chop down a tree, and I will spend the first four sharpening my axe.'Therefore, the key to overcome crisis with effective communication is formulating a plan that possess the capability of turning a negative experience into a positive message about the brand and the company as a whole.

Crisis communication is piloted in very intricate conditions accompanied by range of factors which influence the measures taken and decides their outcome. To some extent this limits the execution of solutions, but does not rule them out. Much depends on how critical the situation is and what risk it has to on its potential consumers. Therefore, it is very important to quickly identify the incidents that conveys inappropriate message and can thus be transformed in most effective way. Compared to the past, progressive developments of brands today are convoyed by quickly emerging influences where the span of meaning changes, with a consequential impact on the process of crisis communication. There is a need to creatively abandon the traditional approaches and analyze these incidents in a more strategic context.

Luecke (2004) Communication through an effective media strategy is fundamental in overall crisis management in order to suppress speculations and bringing forth the actualities to control the way a brand is perceived. Thus, having a comprehensive plan before hand is very significant. As seen in [Figure 1] a model has been 
developed and executed for handling the communication based on some commonly raised questions to assess the crisis critically. Joharet al.(2010)

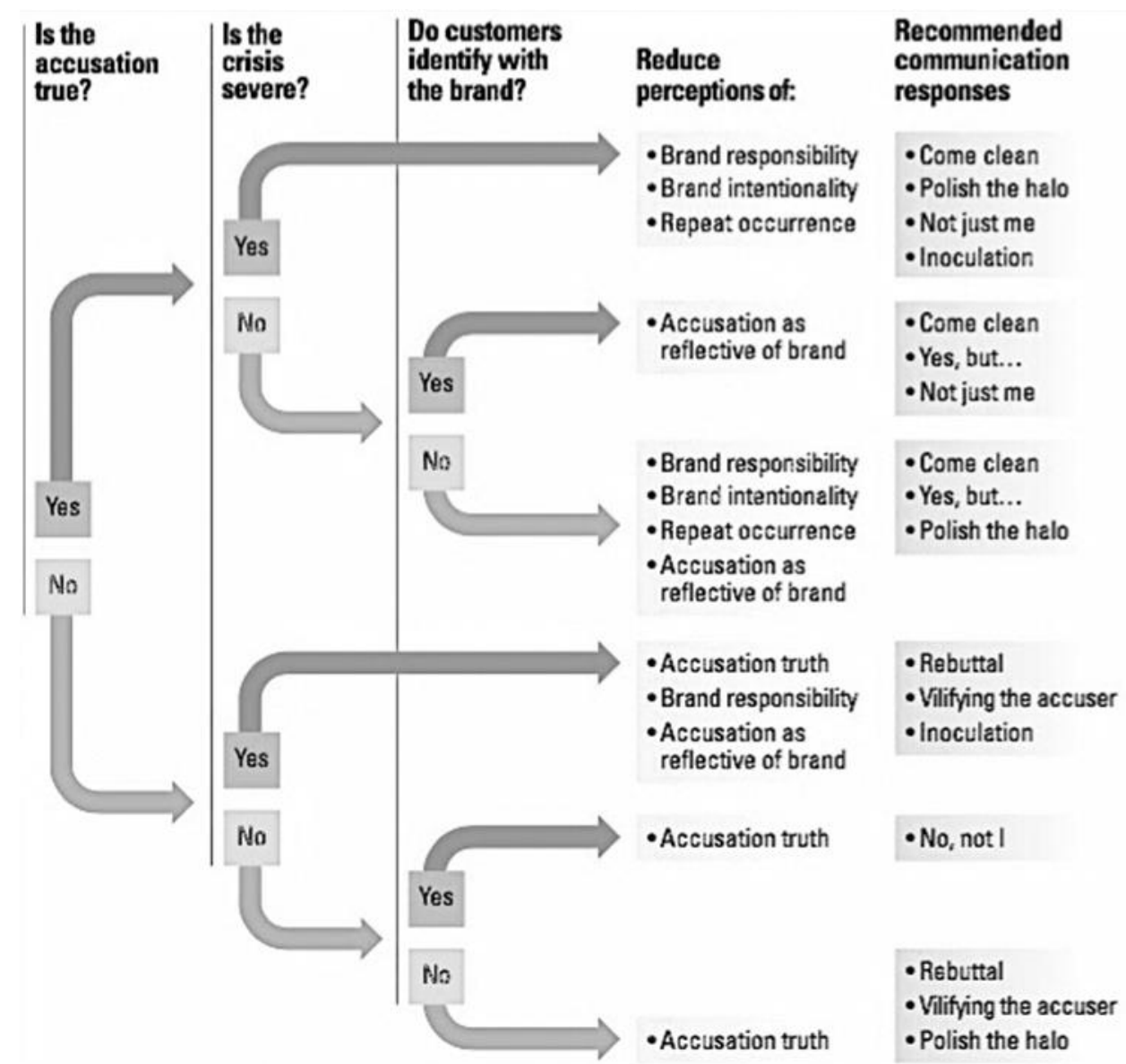

Figure 1 -Model that significantly explains Crisis Communication Network

\subsection{Crisis Communication and Mass Media}

In the present-day society, meanings are structured and observations about any risk are resolved by communication networks, which has increasingly been dominating the diverse social system. Moreover, today media has become a mere necessity to stay connected to the world we live in, to be informed about what's

happening all around and to top it all with hypothesizing the risks linked with our lifestyle and

purchase decisions. (Yannopoulou et al. 2011)

In recent years, the game has changed for crisis communication in India. The users have now certain expectations from the brands towards a disaster or a crisis, which includes open and ethical communication, rapid response and an open dialogue through Social Media which is considered as the most powerful media in today's time. Never before have people been able to reach out directly to a brand as easily as they can now be using these social platforms like Twitter,
Facebook, Instagram etc. Social media is like a dynamic tool in crisis situations, by informing us of where the brand stands currently in the market and it also appears to take brands beyond the crisis. It enables the team behind the curtains to evaluate the exact reason to identify the extent of the problem, to analyze how discussion is progressing and also to identify how B2C messages can grab maximum attention with a recall value. All the brands can make wonderful use of social media for their marketing and to reach masses across the globe. But, this reach may havearound trip, with users sharing their experiences, stories, pictures or videos for the world to see which eventually may have negative connotations attached towards the brand. Therefore, it is critically essential for each brand now days to think of a social media plan that can survive through such digital buzz. 


\subsection{Articulating a plan for Communication}

One such plan can comprehensively embrace the details about the prospective consumers along with their contact information for an intended messaging. Therefore, it is important to have information of each potential user that is easily accessible during such situations. It also comprises of a detailed wordlist of crisis terminology to certify that communication language is apt and consistent. Whenever such situation occurs, brand makers must know whom to contact, when and how without any delays. It is worth mentioning that at times crisis may be pro-longed and connecting, when it is seen that a new crisis may occur preceding the existing one comes before its culmination. Thus, an effective plan gives a solidarity to survive in current Indian industry settings. Importance of creativity continues to garner attention in such situations, where creativity is certainly viewed as a fundamental element to bring in innovation that drives brands business over the significance of crisis communication which has a direct impact on its consumers. The use of the term 'crisis' in public suggests a significant shift in the overall brand usage. The crisis communication approach works as a defensive and dismissive strategy.

\subsection{Framework for Crisis Communication}

The main objective of a framework is to strengthen a community's preparations for emergency situations ensuring a timely, efficient and effective response. Also, to advocate for prioritizing resources for immediate support. 4 main crisis communication strategies that fall under this framework are-

- Rebuilding Strategy- Build with a purpose to reestablish relationships with consumers and stakeholders by restoring the brand's reputation over an accountability for the crisis and offering regrets to those affected by the outcome.

- Diminish Strategy- aims to decrease the brand's accountability by simply justifying their actions. It is normally used in response to crisis where the brand is not at fault for the matter.
- Deny Strategy- Often conceptualized to take away the blame from the brand on the basis of unacceptable allegations.

- Bolster Strategy- A strong enough approach to position the brand amongst its stakeholders with all its advantages attached with a recall value of its earlier noble endeavors and acknowledging their perseverance.

\section{Literature Review}

The literature of crisis communication in the Indian industry of brands has seen a substantial growth in recent times and this all has occurred with the unintended and uncertain events which eventually lead to a downturn in overall brand positioning.

- According toDahlen\& Lange (2006), "brand crisis is like a communicable spread which can not only shake a specific product category but may also have influence on competing brands. He feels, a brand crisis is competent enough to swipe off an entire category by increasing its apparent risk.

- Crisis communication has now developed as a dedicated action plan in the department of public relations to overcome the unintended probabilities and articulate business endurance strategies (Weiner, 2006).

- Fearn-Banks, 2010 also laid down a similar view that a crisis brings with it enough potential to detriment a company or a brand along with its stakeholders.

- Augustine, 2000; Luecke, 2004; FearnBanks, 2010; Greyser, 2009; Hegner et al., 2014 through their research studies had come to a common consensus that to overcome any crisis preparation and communication should come together as a combined force to effectively handle it. Crisis may be at times superior or inferior. It is an impulsive occurrence with a random outcome which nobody can think of. With any crisis situation, not only the 
people or brand's reputation goes for a toss but also the services and finances gets hampered (Fink 1986).

- Greyser (2009) managed an in-depth research on impact of crisis on brand. He testified that there may be number of internal or external issues that leads to concern and thus he also suggested some ways to overcome this.

- John Gerzema\&Lebar, 2008 came up with an astonishing observation that its faithfulness that defines a brand value not its strength or promises.

- Hobbs, 1995; Benson, 1988 further addsthat even a single crisis holds the potential to devastate a brand reputation built in years.

\section{Problem Statement}

Given Crisis situations prime importance to each brands success and its global footprint, it has been the subject of intense research but despite this, understanding remains fragmented often resulting in inconsistent outcomes \& conflicting impressions. It often appears that existing crisis research may suffer from the threat of validity. Therefore, it is critical to investigate the nature \& extent of volatile circumstances and underpinning the approaches adapted by brands to make judgements, built upon ideas that are promising and sustainable.

\section{Aim of the Study}

- To understand brand crisis from the perspective of 3 main phasesidentification, prevention and management.

- To evaluate the relation between crisis and brand reputation.

- To understand challenges that brands face in such volatile circumstances.

- To emphasis upon a brand's action through the crisis or immediately after it.

\section{Hypothesis}

A null hypothesis is framed as under:
H0: A significant relation could not be seen between a crisis situation and brand image.

\section{Methodology}

\subsection{Case Studies}

\subsubsection{Nestle Maggi}

Maggi Noodles were first introduced in India by Nestle in 1982. Although the Indian population was not very familiarized with the habit of consuming canned or packed food, Nestle introduced this product with the clear intention of targeting working women who couldn't cook because of their busy work schedules and therefore could find this type of product very convenient. However, this strategy didn't work well in terms of sales. So, to have a clearer view of what was the cause of this failure, Nestle India conducted a research in which they found that the target audience was different than what they expected. The children were the ones who liked the taste of Maggi Noodles more and therefore a change in the marketing strategy to address the costumers had to be done.This controversy had become an eye opener for many food products industries in India. In June 2015, the FSSAI (Food had declared ban on Maggi Noodle in India after being found "unsafe and hazardous" for consumers due to the presence of lead, apparently beyond permissible limits. A brand that used to rule the market with around $75 \%$ market share since ages saw a setback and the entire sales went down drastically.To win back the trust, Nestle India came up with its series of advertisements [Figure $2 \&$ Figure 3] on all digital media platforms without any brand name but just one thing appearing on the screen "We miss you too".

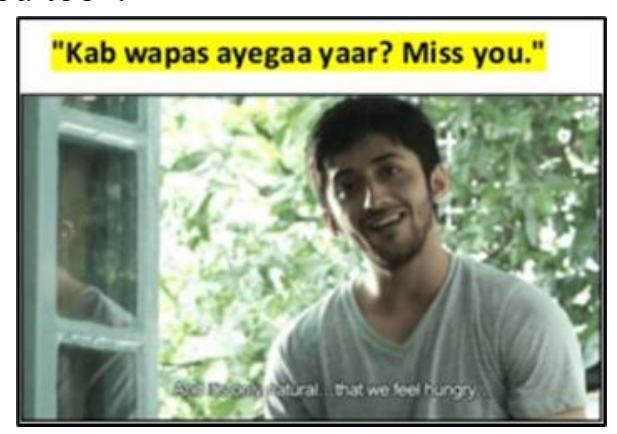




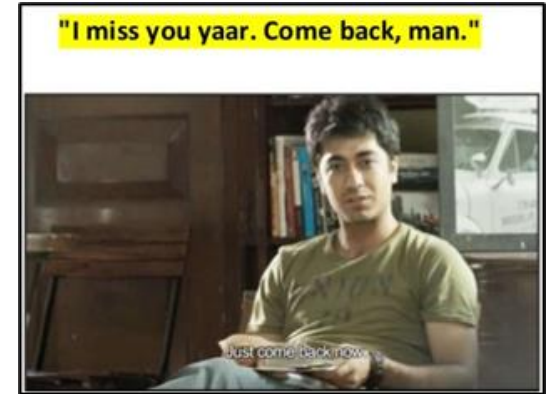

Figure $2 \&$ Figure 3 - The first repositioning digital media campaign by Maggi post crisis

Another one was the Social media campaign [Figure $4 \& 5$ ] resonating with the emotion of nostalgia where a mother shares that how she has used Maggi for her children from last 10 years but never faced any problem.
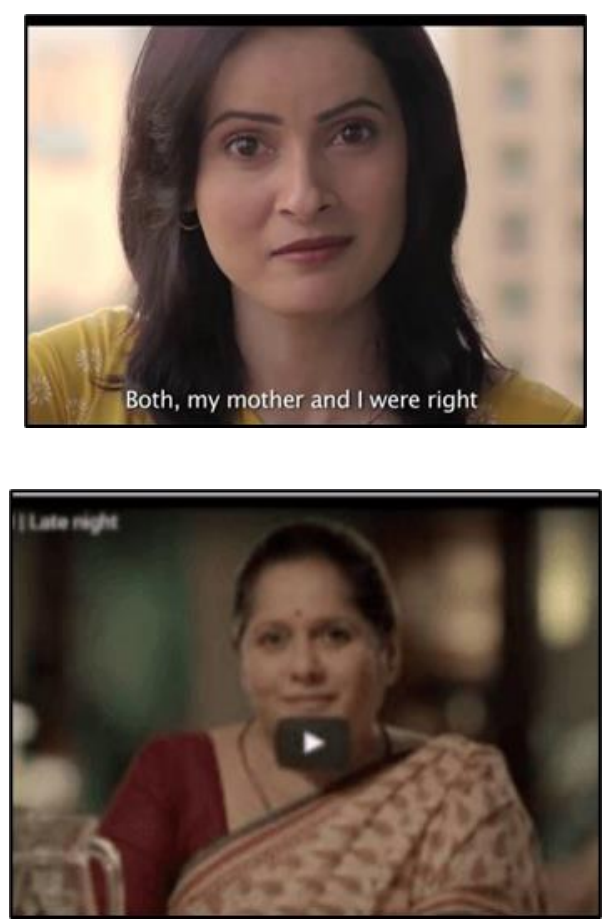

Figure 4 \& Figure 5 - Stills from the social media campaign by Maggi underpinning the emotional brand attachment with its consumers over the years

The \#ashtag campaign [Figure $6 \&$ 7] by Nestle Maggi also became quite popular while talking about brand positioning in market, nothing beats the power of mouth publicity and what can speak more than a Hashtag on social media.
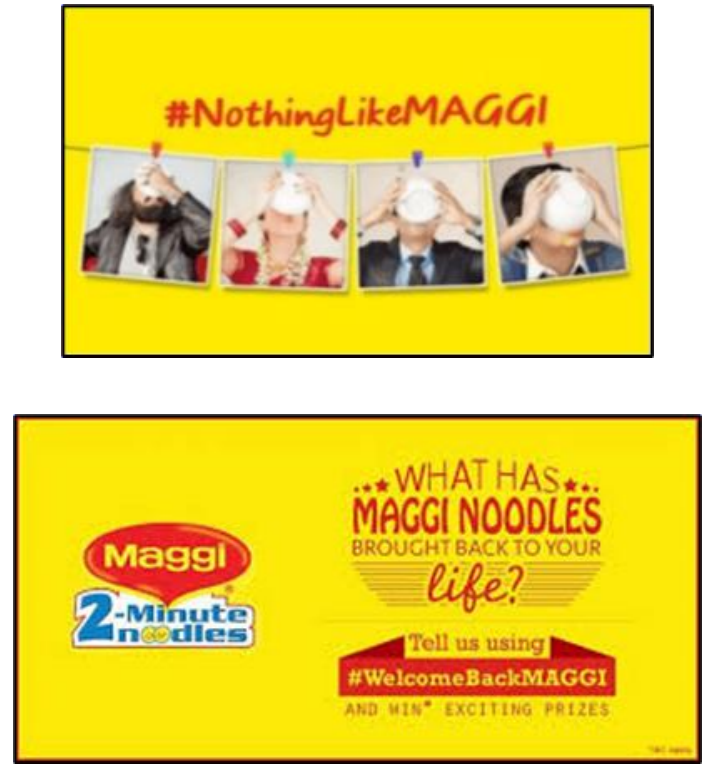

Figure 6 \& Figure 7 - The hashtag social media campaign to empower brand Maggi's repositioning in the Indian market like a new age revolution

Besides all these, Maggi also tied-up with Snapdeal [Figure 8] just to make its product exclusive to imbibe people for an immediate and bulk purchase reacting to the urgency of the moment.

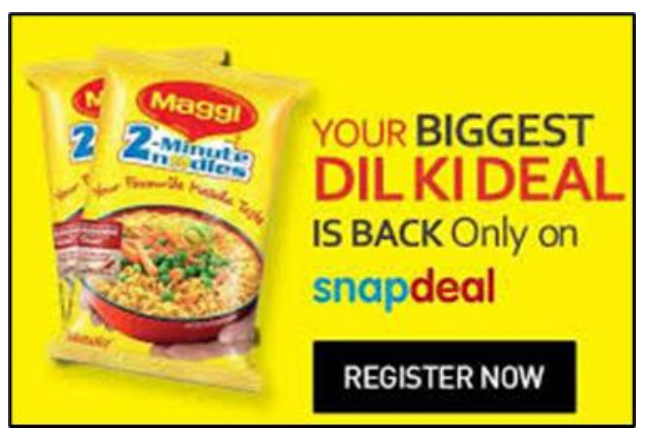

Figure 8 - Declaration of the big collaboration of Maggi with Snapdeal to heat up the market with its limited and exclusive purchase platform

\subsubsection{Cadbury Dairy Milk Chocolate}

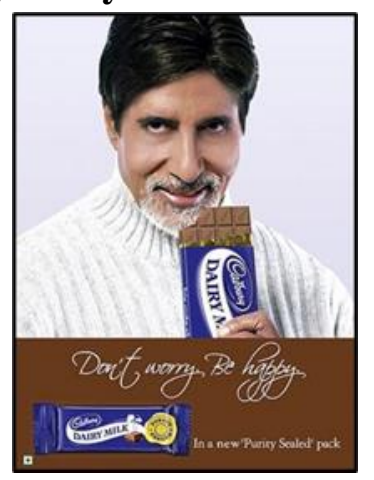


In October 2003, FDA Commissioner of Maharashtra, India got allegations about infestation of worms in bars of Cadbury Dairy milk [Figure 9]. With the negative media publicity spread like wildfire, the company's reputation and credibility suffered extensive damage. Cadbury then set the objectives for crisis communication by saying "Let the brand's performance speak for it".

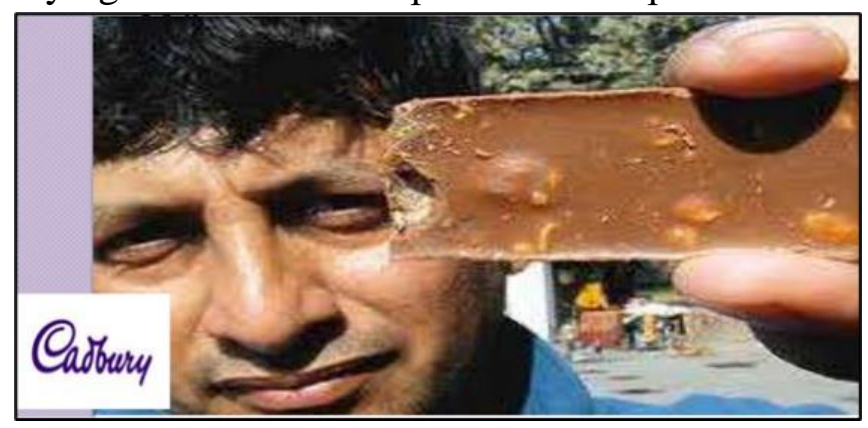

Figure 9 - An FDA officer holding a Cadbury bar with worms as evidence to the whole controversy. Figure 10- The repositioning campaign endorsed by Amitabh Bachchan introducing the new "purity sealed' packaging of Cadbury Dairy Milk.

They came with a damage control plan called "PROJECT VISHWAS", involving distribution and retail channels to ensure the quality of its products. It included-

- A prompt media desk to answer all media queries/clarifications

- Core messages

- Imparting information to prospective Consumers to take care of storage on their part too

- Vended monitoring and education program

- Suggestive \& worthy packaging

- Toll free no and email for easy access

A new 'purity sealed' metallic poly-flow packaging was introduced with a double wrapping to enable determined protection to curb the possibility of any infestation. Mr. Amitabh Bachchan was roped in as brand ambassador to endorse via audio-visual modes in a Testimonial ad campaign [Figure 10].

\subsubsection{Zomato}

One of the outdoor ad campaign of the online mobile application for ordering food grabbed everyone's attention and got them talking. The ad had content as MC.BC. (mac n' cheese, butter chicken) which raised lot of negative connotations and reactions from people [Figure 11]. Angry viewers lashed out at the same. This crisis situation was taken by the brand head-on and was not contradicted. Immediately, to replace this ad the brand tweeted about their new ad to acknowledge their slipup in a quirky way, by using a value added emotional strategy that customers can now avail a $10 \%$ cash-back by using the promo code 'OUTRAGE'. This way the brand managed to spun around the humiliation that burnt up boldly.

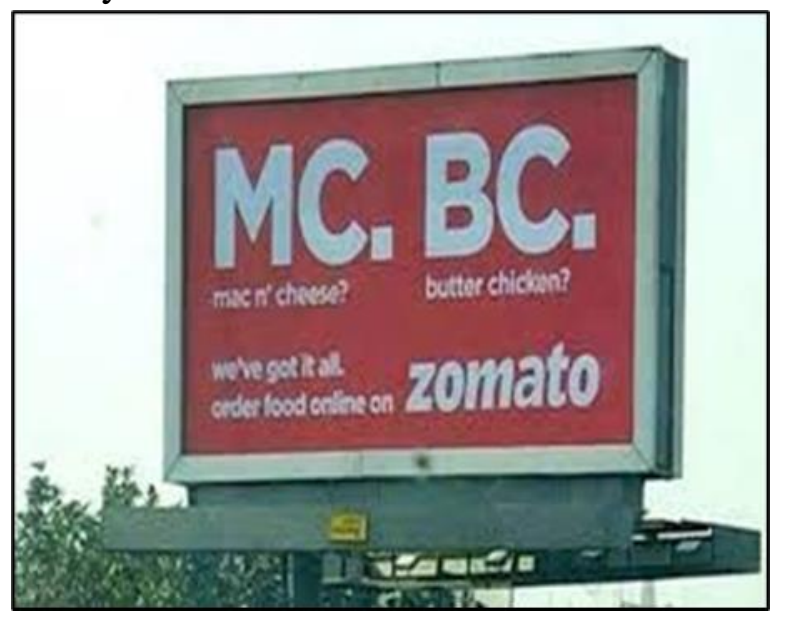

Figure 11 - The hoarding that took brand Zomato in the trap of controversy

\subsubsection{Coca Cola India}

This brand has been the favorite of controversies several times ever since it entered India. Firstly, India Resource Center (IRC) suspected Coca-Cola of emitting wastewater into the fields around its bottling plantsthat are meant for agricultural purposes. The brand was highly criticized for reducing groundwater slabs, leaving the local communities with no water for drinking as well as agricultural purposes which eventually affected their core occupation to earn a living. The brand also faced allegations that it had confiscatedfarmers land to discharge its waste which is hazardous and slurry. Later, Centre for Science and Environment (CSE), declared Cola unsafe due to high levels of pesticide residues." While assured of all the safety needs being fulfilled, Coke still decided to run campaigns in both rural and urban India to reestablish public confidence and avoid unintended 
consequences. In rural society where Coca Cola was considered a luxury, they also launched its small bottle for half the price as a treat for rural people to also enjoy it.[Figure 12]

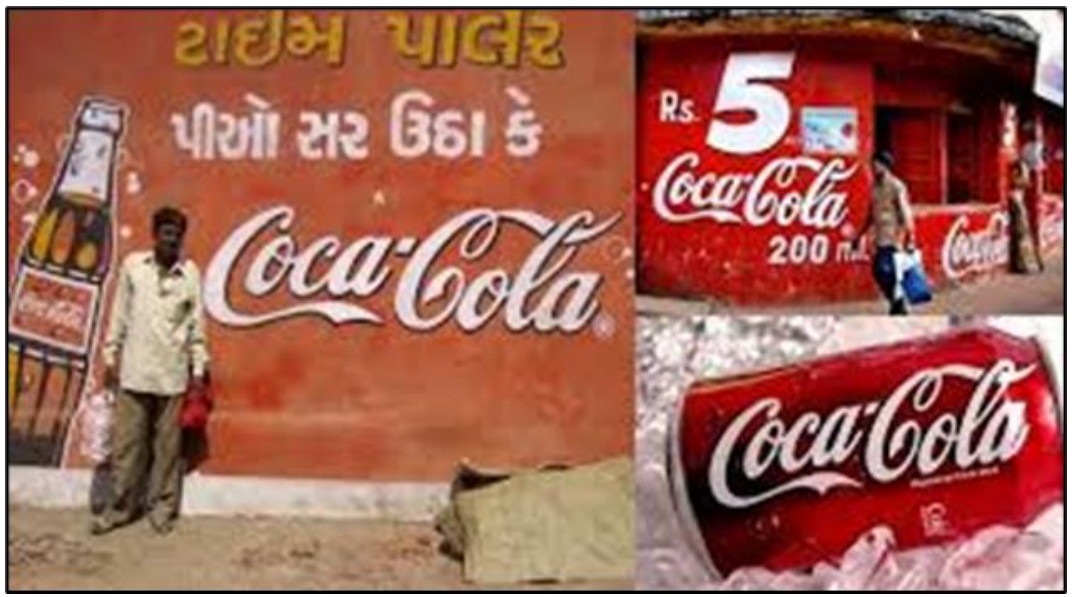

Figure 12 - Outdoor promotions of Coke introducing their small packaging in rural India

\subsection{Data Collection \& Sample}

To map the impact of crisis and its influence on brand consumers, I thought of taking quantitative and exploratory approach, including both sources of data collection: Primary and Secondary data. Secondary data comprised of literature review and case studies. Simulations and observations from case studies were also helpful in stemming a better understanding towards the objective.Insights drawn from the secondary research helped in articulating the questionnaire to collect information as Primary data, which was further assessed and analyzed through statistical techniques. Opinions from a total of 100 respondents who were either brand experts, marketing executives, creative/ PR teams or crisis management specialists with brands from different Tier $1 \&$ Tier 2 cities of India have been used to validate the study.Convenience sampling method has been followed for collecting the response.

\subsubsection{Constructing the questionnaire}

Figure13signifies the questionnaire in form of a flowchart with the order used for data collection. The first question was aimed at identifying the awareness/ acquaintance of brand professionals with such communication. After that, second question onwards, I intended to ask the respondents about their experiences in context of crisis communication for a brand. I also asked them to support their responses with critical thoughts in Question 9 and 10 which were aimed at giving the respondents an opportunity to suggest some effective communication techniques that may be taken into consideration for better impact. To get a more qualitative view, question 11 focused on their take away from the brand case studies as to how they articulated their communication strategies in such difficult circumstances. 


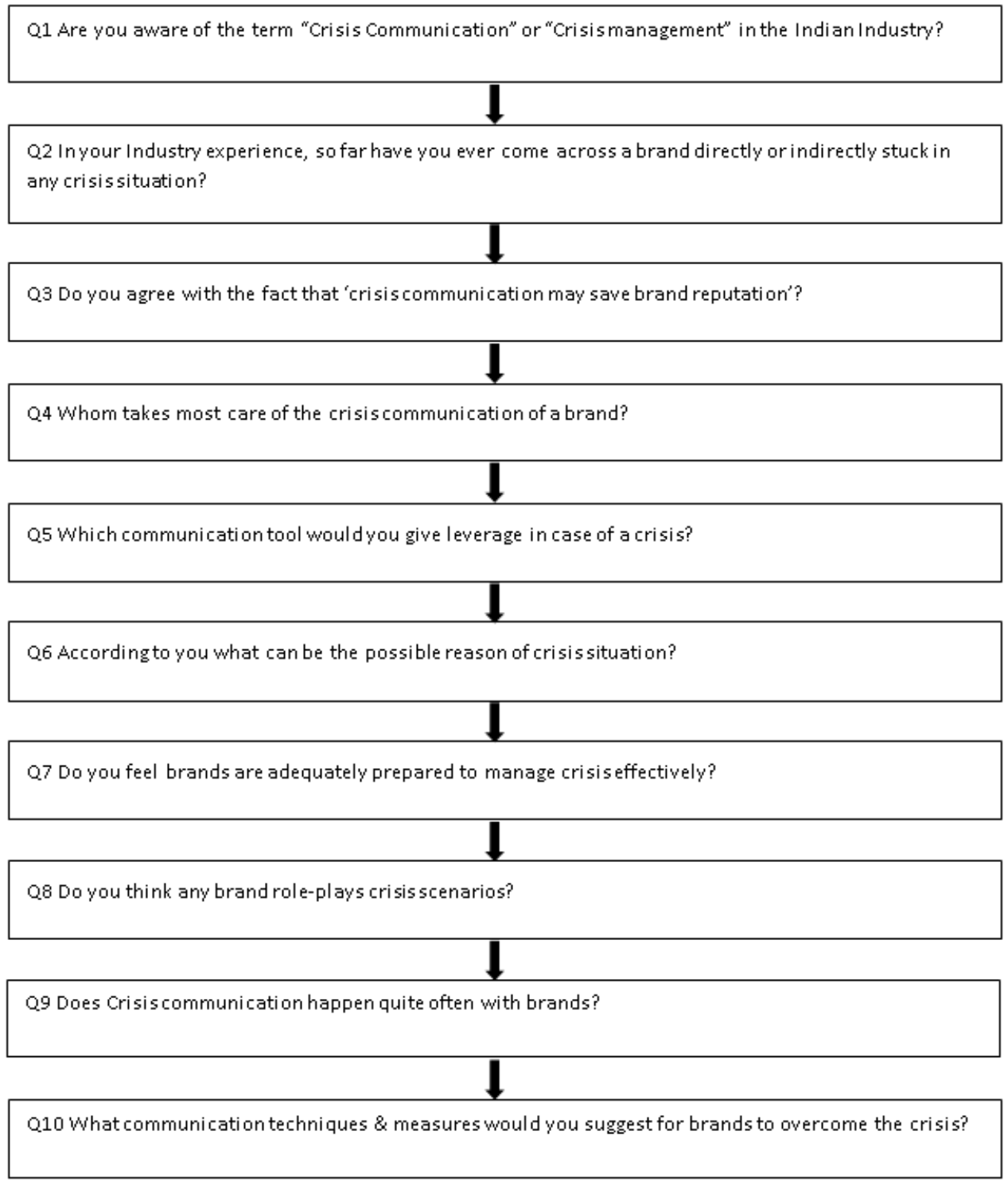

Figure 13 - Questionnaire structured for the primary data collection (Qualitative \& Quantitative)

\section{Analysis \& Interpretation}

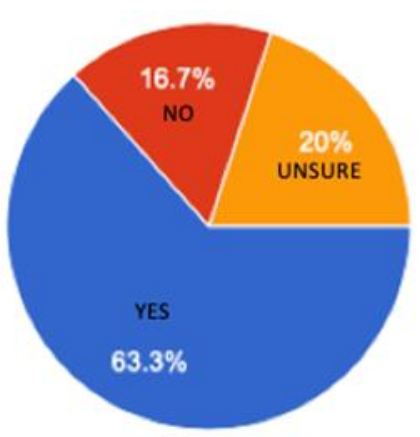

Chart 1. Awareness about Crisis Communication
The collected data has been charted below to draw interpretations on which descriptive statistics with percentage analysis were built.

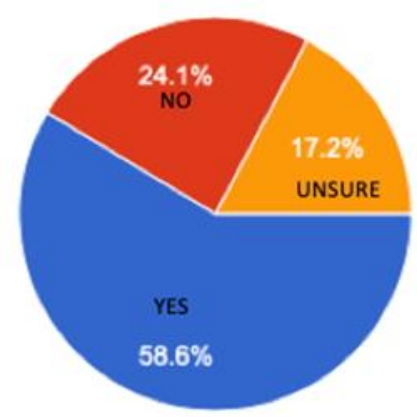

Chart 2. Personal Experience working on brands who have faced crisis 


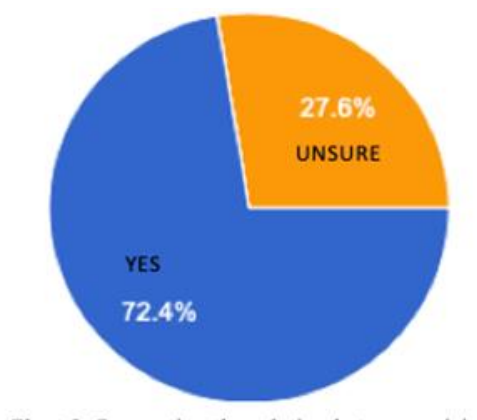

Chart 3. Supporting the relation between crisis communication \& brand reputation

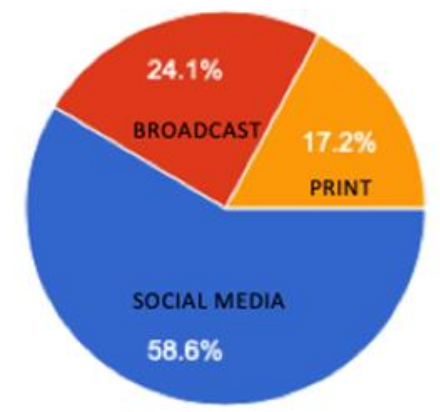

Chart 5. Preferable Media for crisis communication

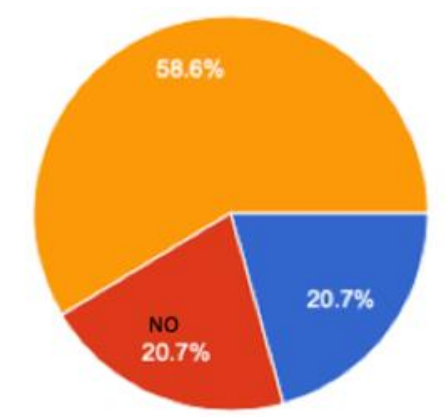

Chart 7. Are brands today prepared to manage crisis?

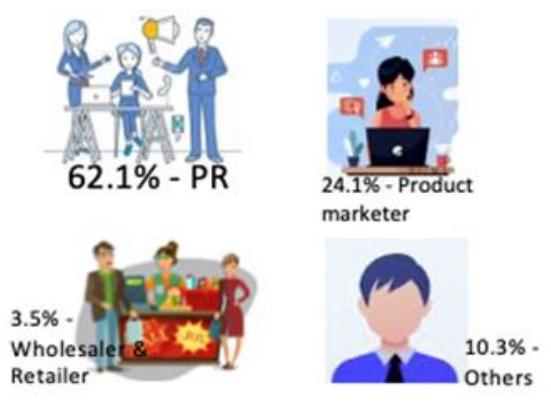

Chart 4. People behind crisis communication

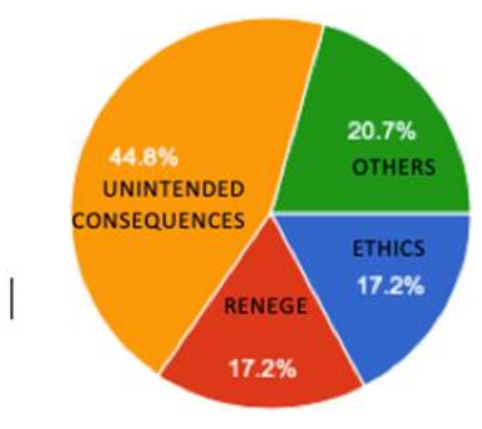

Chart 6. Possible reasons of crisis

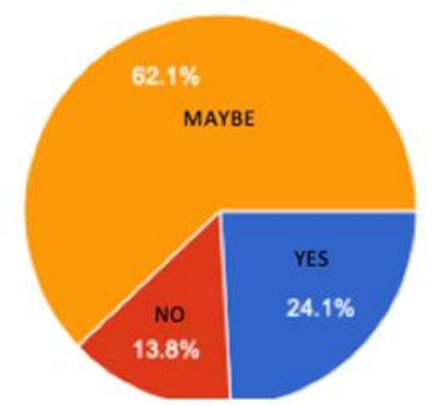

Chart 8. Do current brands role play crisis scenarios?
Findings from the last set of questions were suggestions from the respondents that in each crisis communication, it is important to have a direct and right approach to the prospective customers which could also be enhanced with regular engagement through brand awareness activities. Besides this, they also suggested that both internal and external communications have to be effectively delivered setting an example for the industry to follow. Consolidating the brand positioning and rethinking of a brand strategy can also be a wise step. Brand makers should connect with the team frequently keeping transparency to access the plan for its accuracy. According to them, since most of the crisis communication is gong trough online platforms now days, ORMObject relational mapping can be the best way to handle it. On asking them about their observations in context of some brand crisis stories/ cases, they responded that it is quite evident that most brands have succeeded in changing their brand positioning post a successful crisis communication campaign. A fact was also highlighted that at times, it's not the brand intervention but the legal team that takes over the charge. They said, in Nestlé's Maggi crisis,communicating the facts well has proved to be more important than the facts themselves. 


\section{Conclusion}

In today's digital era, within a flash of second any news may go viral whether it's good or bad. Therefore, Indian brands are now more vulnerable to their stained image. Throughout this study, it is found that along with an immediate response crisis communication may also minimize any negative consequence in long- term. The term "unintended consequences" is certainly a barrier to the vital growth of the brand but it does provide an opportunity to understand the consequences more broadly. Instead of rendering criticism for any sort of blame game, we can see it as an opening for meaningful intellectual engagement. Attentiveness towards crisis communication could serve as a starting point for fostering imaginative and collaborative engagements imbued with possibility. Today, a brand has nowhere to hide especially the ones that lag in momentum, innovation and creativity. If any brand has been blown, it may need to give its potential consumers a motive to rebuild the belief bybuilding the experience that lives up to the core promise. Hence forth, creativity can be the best approach to avoid this brand bubble. Consumers now days frequently shift to brands with new \& innovative strategies with all socio-economic and emotional considerations, and for this a brand has to keep being different yet loyal.

Preparedness action is carried out within the context of crisis management and should be based on a comprehensive analysis of risks and be well connected to early cautionary methods. It includes emergency planning, stand-by arrangements, communications, information controlling and public awareness etc. Brand should attach more importance and substance to its product to avoid being targeted to controversies. Brands needs to re-formulate their soul and distinct characteristics mapping them to the Indian standards and regulations and highlight what distinguish a cult brand to an average one. The crisis communication plan should not be for a specific time duration, rather it must be constantly assessed, verified and rationalized. Alongside, capitalizing in corporate social responsibility events, engagement with a credible endorser and building strong public associations would also help recuperate customer conviction. Effective handling of crisis is of prime importance, to strengthen brand alliance with its users. istepthis study also throws light on an interesting finding that the crisis management action that a brand takes may not be critical enough to regain market share. It is observed that a company's control over buyers purchase decisions minimizes when a brand falls in trap of a crisis. And therefore, it is essential to protect and ensure buying behavior from dips.

Finally, nothing can sum up my area of inquiry better than this inspirational quote by Warren Buffet saying "It takes 20 years to build a reputation and five minutes to ruin it. If you think about that, you'll do things differently" (Tuttle, 2010).

\section{REFERENCES}

[Books]-

[1] Augustine, N. (2000). Harvard business review on crisis management. Boston: Harvard Business School Press.

[2] Fearn-Banks, Kathleen (2010). Crisis Communications: A casebook approach. New York: Routledge publishers.

[3] Luecke, R. (2004). Crisis management. Boston: Harvard Business School Press.

[4] Ulmer, R.R. et.al. (2007). Effective crisis communication: Moving from crisis to ičpiopportunity. Thousand Oaks: Sage Publications is[epi

\section{[Article in Print Journal]-}

[5] Aaker, David A. (1990). and Keller, Kevin Lane. (1990). Consumer Evaluations of Brand Extensions. Journal of Sicpipinarketing, 54 (1), 27-41. iLئ日:

[6] Benson, J.A. (1988). Crisis Revisited: An Analysis of Strategies Used By Tylenol In The Second Tampering Episode. Central 
States Speech Journal, 39(1), 49-66. istep

[7] Coombs, W.T. (2007). Protecting Organization Reputations during a Crisis: The Development and Application of Situational Crisis Communication Theory. Corporate Reputation Review, 10(3), 163-

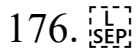

[8] Dahlen, Micael. (2006, Dec). and Lange, Fredrick. (2006, Dec). A Disaster is contagious: How a brand in crisis affects other brands. Journal of Advertising Research, Vol.46(4), p388-397.

[9] Fink, S. (1986). Crisis management: Planning for the inevitable. New York: AMACOM. is

[10] Farte, Gheorghe-Ilie. (2013). Emotion Management in Crisis Situations. Journal of the Seminar of Discursive Logic, Augmentation Theory and Rhetoric, Vol.11 (2). pp.59-70.

[11] Greyser, S.A. (2009). Corporate brand reputation and brand crisis management. Management Decision, 47(4), pp.590-602. doi:

http://doi.org/10.1108/0025174091095943 1

[12] Hegner, S. et.al. (2014). How company responses and trusting relationships protect brand equity in times of crises. Journal of Brand Management, 21(5), pp.429-445.

[13] Hobbs, J.D. (1995). Treachery by any other name: A case study of the Toshiba public relations crisis. Management communication quarterly, 8(3) 323-346. ičpep

[14] Herbig, Paul. (1995) and Milewicz, John. (1995). The relationship of reputation and credibility to brand success. Journal of Consumer Marketing, Volume 12 (4), pp. 5-10(6).

[15] John, Gerzema. (2008) and Ed, Lebar. (2008). The Brand Bubble: The Looming Crisis in Brand Value and How to Avoid It, Jossey Bass: San Fransisco. istepi

[16] Mehta, Rhuta. et.al.(2013). Corporate Social Responsibility in India: A reality, a philosophy or a new marketing strategy. Sankalpa: Journal of Management \& Research, Vol.3. p.56-60

[17] Panda, Rasananda. (2015) andKarani, Anushree. (2015). Corporate Social Responsibility: A Way for Image Management. Asian Journal of Research in Social Sciences and Humanities, Vol.5 (12). p78-89. ISSN 2249-7315

[18] Savelli, Elisabetta. (2011). Role of brand management of the luxury fashion brand in the global economic crisis: a case study of Aeffe Group. Journal of Global Fashion Marketing, pp.170-179.

[19] Yannopoulou, Natalia et al. (2011, May). Media amplification of a brand crisis and its effect on brand trust. Journal of Marketing Management, Vol. 27(5/6), p530-546.

\section{[Article in Online Journal]-}

[20] Johar, G. et.al. (2010). How to Save Your Brand in the Face of Crisis. [online] MIT Sloan Management Review. Available at: http://sloanreview.mit.edu/article/how-tosave-your-brand-in-the-face-of-crisis/ [Accessed 6 Mar. 2017].

[21] Salvador, Alexandre Borba. (2017). and Ikeda, Ana Akemi. (2017). Brand crisis Management: the use of information for prevention, identification and management. RBGN-FECAP Review of Business Management, p74-91. E-ISSN 1983-0807. doi: 10.7819/rbgn.v20il.3583

[22] Salvador, Alexandre Borbaet.al (2017). Crisis Management and its impact on brand image. Gest.Prod., SaoCarlos, vol.24(1), p.15-24.

doi: http://dx.doi.org/10.1590/0104-530X166814.

[23] Weiner, David. (2006). Crisis Communications: Managing corporate Reputation in the court of Public Opinion, The Workplace, available at 
http://iveybusinessjournal.com/topics/theworkplace/crisis-communicationsmanaging-corporate-reputation-in-thecourt-of-public-opinion\#.VM8cuNKUcwA

\section{[Magazine - Print]}

[24] Savira. (2015, Feb). How to deal with Crisis. Up.Date.- Media, Communications and E-Commerce, Vol (02), pp.44-45.

\section{[Websites]}

[25] https://www.google.com/url?sa=t\&rct=j\&q $=\&$ esrc $=\mathrm{s} \&$ source $=$ web $\& \mathrm{~cd}=\& \mathrm{cad}=\mathrm{rja} \& u a$ $\underline{\mathrm{ct}=8 \& \mathrm{ved}=2 \mathrm{ahUKEwipuNKOld} \_ \text {sAhUafS }}$ sKHd_uA14QFjAAegQIBBAC\&url=https $\% 3 \mathrm{~A} \% 2 \mathrm{~F} \% 2 \mathrm{Fwww}$.talkwalker.com\%2Fbl og\%2Fcrisis-

communication\&usg=AOvVawljqkqudwP E0PWqVJHulVE8

[26] https://www.google.com/url?sa=t\&rct=j\&q $=\&$ esrc $=$ s \& source $=$ web \& $c d=\& c a d=r j a \& u a$

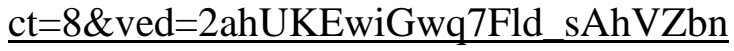
0KHXmmDFgQFjAAegQIAxAC\&url=htt ps\%3A\%2F\%2Fbrandequity.economictime s.indiatimes.com\%2Fnews\%2Fbusinessof-brands $\% 2$ Fwhen-crisis-hits-yourbrand\%2F69713009\&usg=AOvVaw3HelfeSrrMcpdHxMP 91R

[27] https://www.google.com/url?sa=t\&rct=j\&q $=\&$ esrc $=$ s $\&$ source $=$ web $\& c d=\& c a d=$ rja $\& u a$

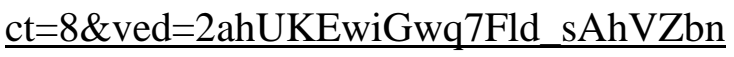
0KHXmmDFgQFjAJegQIAhAC\&url=http s\%3A\%2F\%2Fwww.brandextract.com\%2 FInsights\%2FPodcast-Episodes\%2FHowto-Manage-a-Brand-Through-a-

Crisis\%2F\&usg=AOvVaw3p4R63gYKBIg o9n_9h7fvW

[28] https://www.google.com/url?sa=t\&rct=j\&q $=\&$ esrc $=$ s \& source $=$ web $\& c d=\& c a d=r j a \& u a$

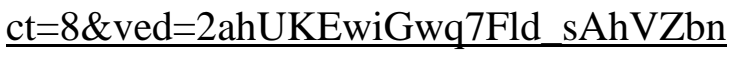
0KHXmmDFgQFjALegQIGRAC\&url=htt ps $\% 3 \mathrm{~A} \% 2 \mathrm{~F} \% 2 \mathrm{Fmention.com} \% 2 \mathrm{Fen} \% 2 \mathrm{Fbl}$ og\%2Fbrand-crisis-to-prwin\%2F\&usg=AOvVaw1cpBttkIkkAObQ $\underline{\text { Xjkrkbwf }}$
[29] https://www.google.com/url?sa=t\&rct=j\&q $=\&$ esrc $=$ s\&source $=$ web $\& c d=\& c a d=r j a \& u a$ $\underline{\mathrm{ct}=8 \& \mathrm{ved}=2 \mathrm{ahUKEwiGwq7Fld} \mathrm{sAhVZbn}}$ 0KHXmmDFgQFjAQegQIGBAC\&url=htt ps $\% 3 \mathrm{~A} \% 2 \mathrm{~F} \% 2 \mathrm{Fbrand} 24 . \mathrm{com} \% 2 \mathrm{Fblog} \% 2$ Fbrand-reputation-crisis-

management\%2F\&usg=AOvVaw3LXmgot BXGVZfk2io73kYF

[30] https://www.google.com/url?sa=t\&rct=j\&q $=\&$ esrc $=$ s\&source $=$ web $\& c d=\& c a d=r j a \& u a$ $\underline{\mathrm{ct}=8 \& \mathrm{ved}=2 \mathrm{ahUKEwiGwq7Fld} \text { sAhVZbn }}$ 0KHXmmDFgQFjARegQIGxAC\&url=htt ps $\% 3 \mathrm{~A} \% 2 \mathrm{~F} \% 2 \mathrm{Fsloanreview.mit.edu} \% 2 \mathrm{Fa}$ rticle\%2Fhow-to-save-your-brand-in-theface-ofcrisis\%2F\&usg=AOvVaw32bwFNXpabHk_4XY3yRTy 